Tyndale Bulletin 68.2 (2017) 287-312

\title{
KNOWING THE DIVINE AND DIVINE KNOWLEDGE IN GRECO-ROMAN RELIGION
}

\author{
Eckhard J. Schnabel \\ (eschnabel@gordonconwell.edu)
}

\begin{abstract}
Summary
In his 2007 Tyndale Biblical Theology lecture, Brian Rosner has shown that the notion of being known by God is an important, albeit neglected, theme in the Old and New Testament. He explored the three relation notions of belonging to God, being loved or chosen by God, and being a child or son of God. After a concise survey of relevant biblical data in the Old and New Testament, he described the value of 'being known by God' in terms of warning, humility, comfort, and security. The following paper explores Greek and Roman religious texts with a view to establishing whether the notion of 'being known by God' surfaces in the context in which the early Christian movement engaged in missionary work, seeking to win polytheists for faith in the one true God and in Jesus Messiah. New Testament scholars do not seem to have explored the subject of the Greek and Roman gods 'knowing' human beings. Similar to Rosner's biblical theological essay, which surveyed texts without in-depth discussion of exegetical details and historical context, the following essay is wide-ranging, considering primary texts written over a large span of time, from Homer's epics (which continued to be read in the first century), the Homeric Hymns, Xenophanes' fragments, Callimachus' Hymn to Demeter, Cleanthes' Hymn to Zeus, Hesiod's Theogony, Cicero's De natura deorum, and Plutarch's religious texts to the Greek Hymns in the Furley/Bremer collection and the Lydian confession inscriptions.
\end{abstract}




\section{The Difficulty of Knowing the Gods}

That the gods are difficult to know is repeatedly stated in Homer's epics. ${ }^{1}$ Odysseus did not know the identity of the (river-) god to whom he prayed for help: he addresses the god with the words 'Listen, sire,

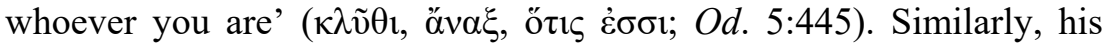
son Telemachos did not know who was the god that arrived in the guise of a human being and departed as a bird (the reader knows that it is Athena): he addresses the god with the words, 'Listen to me, you God

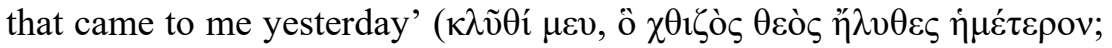
Od. 2:262). Xenophanes of Colophon (sixth century BC) writes:

No man knows, or ever will know, the truth about the gods ( $\tau$ ò $\mu \dot{\varepsilon} v$ oṽv

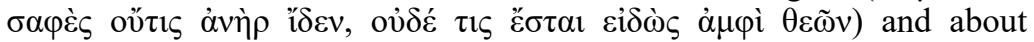
everything I speak of: for even if one chanced to say the complete truth, yet oneself does not know it; but opinion is allotted to all (men). (Frag. $34)^{2}$

In a hymn to the ancestral gods and to Zeus, Aeschylus (525-456 BC) has the girls feel doubt and distance vis-à-vis Zeus (Supplices 86-103): ${ }^{3}$

\begin{tabular}{|c|c|}
\hline $\begin{array}{l}\text { May Zeus' will - if it is truly his! - } \\
\text { bring this to a good end. It is not easily } \\
\text { tracked down, } \\
\text { for the paths of his thoughts } \\
\text { tend to be overgrown, } \\
\text { thick-shadowed, invisible to our eyes. }\end{array}$ & 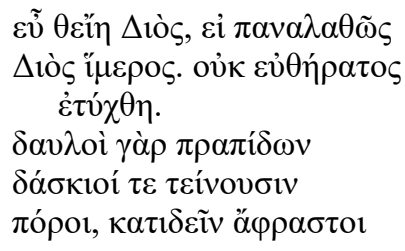 \\
\hline $\begin{array}{l}\text { Whatever Zeus, by a nod of his head, } \\
\text { has decided to fulfill, } \\
\text { lands safely, not falling on its back }\end{array}$ & 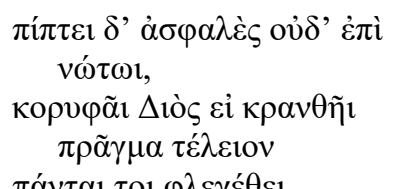 \\
\hline it shines 1 & 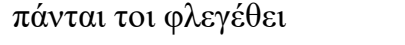 \\
\hline
\end{tabular}

1 Homer, Il. 20.131; Od. 13.312; 16.161; Hom. Hymn. Dem. 111; cf. Hendrik S. Versnel, Coping with the Gods: Wayward Readings in Greek Theology (Religions in the Graeco-Roman World 173; Leiden: Brill, 2011), 38-39.

2 Geoffrey S. Kirk, John E. Raven, and Malcolm Schofield, The Presocratic Philosophers, 2nd ed. (Cambridge: Cambridge University Press, 1983), 179.

3 Martin L. West, Aeschyli Supplices (Bibliotheca Scriptorum Graecorum et Romanorum Teubneriana; Stuttgart: Teubner, 1992); cf. William D. Furley and Jan Maarten Bremer, Greek Hymns: Selected Cult Songs from the Archaic to the Hellenistic Period, vol. 1 (Studien und Texte zu Antike und Christentum 9-10; Tübingen: Mohr Siebeck, 2001), 280-85; William D. Furley and Jan Maarten Bremer, Greek Hymns: Greek Texts and Commentary, vol. 2 (Studien und Texte zu Antike und Christentum 9-10; Tübingen: Mohr Siebeck, 2001), 241-45; cf. Pär Sandin, Aeschylus' Supplices. Introduction and Commentary on vv. 1-523 (Göteborg: Göteborg University, 2003), 22. 
even amidst darkness, accompanied by a black destiny for the tribes of men.

From the high castles of their illusions he hurls mortals into destruction,

without mobilizing any violence. Divine action is effortless: sitting, he consummates his thought nevertheless,

from where he is, mysteriously, even from his holy throne'

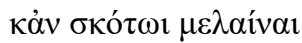

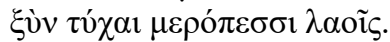

ió $\pi \tau \varepsilon 1$ ' ' $̇ \lambda \pi i \delta \omega v$

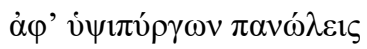

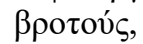

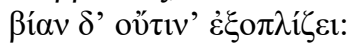

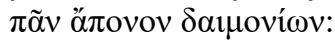

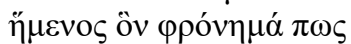

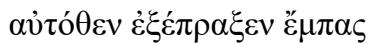

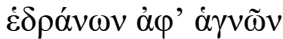

Furley and Bremer comment on the surprising expression of distance and doubt expressed by the girls:

they are not certain which way his decision will fall ... Nor are they certain how precisely his power will make itself felt: they know that he will remain aloof and distant, seated on his holy throne; but even so they are confident that he will put into effect what he has in mind, mysteriously. ${ }^{4}$

Marcus Tullius Cicero (106-43 BC) begins the first volume of De natura deorum with the assertion that the subject of the nature of the gods is difficult:

There are a number of branches of philosophy that have not as yet been by any means adequately explored; but the inquiry into the nature of the gods, which is both highly interesting in relation to the theory of the soul, and fundamentally important for the regulation of religion, is one of special difficulty and obscurity (perobscura quaestio est de natura deorum), as you, Brutus, are well aware. The multiplicity and variety of the opinions (variae sunt ... tamque discrepantes sententiae) held upon this subject by eminent scholars are bound to constitute a strong argument for the view that philosophy has its origin and starting-point in ignorance, and that the Academic School were well-advised in 'withholding assent' from beliefs that are uncertain. (Nat. d. 1:1)

The experience of Asklepios, the god of healing, illustrates the power and the knowledge that Greeks attributed to some of the gods. ${ }^{6}$ Some miracles that are claimed to have happened were truly astounding. In

4 Furley and Bremer, Greek Hymns, vol. x, 283.

5 Harris Rackham, Cicero: De natura deorum. Academica (Cicero XIX; orig. 1933; repr., LCL; Cambridge: Harvard University Press, 1994).

6 For the following remarks cf. Versnel, Gods, 400-19; Versnel makes a strong case that the cultic forms of Asklepios worship are not a completely new trend in fourthcentury Greek religion but 'implicitly inherent in the notion 'god'' (421). 
one of the iamata from Epidauros (IG IV I I 121-122; dated c. 350-300

BC) we read:

Aristagora of Troezen. She had a worm in her belly, and she slept in the Temple of Asclepius at Troezen and saw a dream. It seemed to her that the sons of the god, while he was not present but away in Epidauros, cut off her head, but, being unable to put it back again, they sent a messenger to Asclepius asking him to come. Meanwhile day breaks and the priest clearly sees her head cut off the body. When night approached, Aristagora saw a vision. It seemed to her that the god had come from Epidauros and had fastened her head on to her neck. Then he cut open her belly, took the tapeworm out, and stitched her up again. And after that she became well. (No. 23)

In other accounts of superhuman and supernatural miracles, the god is portrayed as omnipotent, the miracles as examples of unrestricted power:

Ambrosia of Athens, blind of one eye. She came as a suppliant to the god. As she walked about in the Temple she laughed at some of the cures as incredible and impossible, that the lame and the blind should be healed by merely seeing a dream. In her sleep she had a vision. It seemed to her that the god stood by her and said that he would cure her, but that in payment he would ask her to dedicate to the Temple a silver pig as a memorial of her ignorance. After saying this, he cut the diseased eyeball and poured in some drug. When day came she walked out sound. $(\text { No. } 4)^{8}$

In such miracles, as Versnel notes, 'the god can do anything he wants and he knows everything: he is omnipotent and omniscient'. ${ }^{9}$ In his Oration for Asklepios, Aelius Aristides (AD 117-181) claims that 'the

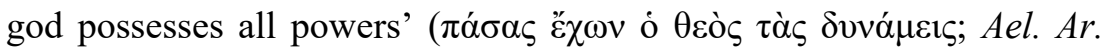
Orat. 42:4). In one of the confession inscriptions from Maeonia, the person who is cured praises the goddess Leto 'who makes the

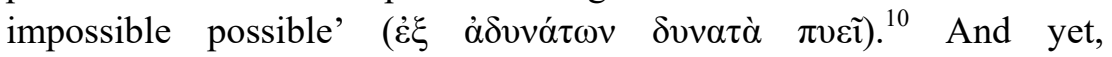
Hippocrates acknowledges that 'even the inventor of the medical art, Asklepios, did not achieve that, but failed in many cases as we can read

7 Emma J. L. Edelstein and Ludwig Edelstein, Asclepius: Collection and Interpretation of the Testimonies, 2 vols (orig. 1945; repr., Baltimore: Johns Hopkins University Press, 1998), vol. 1, 234 (Greek text 225). Versnel, Gods, 404 comments 'Doctors are always engaged elsewhere when your head needs readjustment.'

8 Edelstein and Edelstein, Asclepius, vol. 1, 230 (Greek text 222).

9 Versnel, Gods, 418; the perspective of Asklepios as a god 'does not tolerate restrictions as to type of miracle'.

10 Georg Petzl, Die Beichtinschriften Westkleinasiens (Epigraphica Anatolica 22; Bonn: Habelt, 1994), 140-41 (no. 122). 


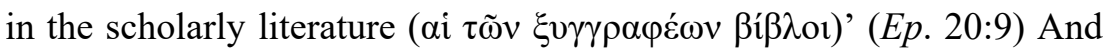
Pliny the Elder (AD 23-79) writes: 'not even a god can achieve anything he wants' (ne deum quidem posse omnia; Hist.nat. 2:27).

The gods have a distinctive personality, constituted by the specific local cult and ritual by which a god is worshiped, by various names for the same god, by the myths that people told about the god and by the cult image. Yet, as Walter Burkert pointed out, 'this complex is easily dissolved, and this makes it quite impossible to write the history of any single god'. ${ }^{11}$ Hendrik Versnel asserts:

no single universal and consistently valid statement can be made about any god, except that he or she is a god (and even that one may occasionally be disputed). Gods alternate between unimaginable sublimity and the basest human behaviour, between supernatural capabilities and occasional frailties, and swiftly they bridge the distance. $^{12}$

\section{Divine Self-Absorption}

According to Greek myth, the gods are often and rather consistently self-absorbed, often envious and resentful. Bernard Knox writes that in Euripides' tragedies the gods 'project on to the enormous scale of the divine those passions which human beings struggle vainly to control in themselves; these passions, in the shape of Olympian gods, selfabsorbed, unrelenting, rule the life of men and women'. ${ }^{13}$

A good example is Demeter. In the Homeric Hymn to Demeter (seventh/sixth century BC), the goddess appears in Eleusis after the abduction of Persephone: she sits 'near the road, grief in her heart' (Hom. Hymn. 2:98). ${ }^{14}$ The daughters of Keleos, son of Eleusis, 'did not

11 Walter Burkert, Greek Religion, trans. J. Raffan (orig. 1977; repr. Cambridge: Harvard University Press, 1985), 119.

12 Versnel, Gods, 438, pointing out that 'Homer perhaps offers the most conspicuous and often alarming examples', n.198, with reference to James M. Redfield, Nature and Culture in the Iliad: The Tragedy of Hector (expanded ed.; Durham: Duke University Press, 1994), 225-47 ('The Gods of the Iliad, Amplification').

13 Bernard M. W. Knox, 'Euripides', in The Cambridge History of Classical Literature I. Greek Literature, eds P. E. Easterling and B. M. W. Knox (orig. 1985; repr. Cambridge: Cambridge University Press, 1996), 316-39, esp. 325. The later myth of Narcissus who was condemned by Nemesis to love his own image reflected in a pool is the epitome of human self-absorption.

14 Text: Nicholas J. Richardson, The Homeric Hymn to Demeter (Oxford: Oxford University Press, 1974); translation: Helen P. Foley, The Homeric Hymn to Demeter: 
know her - gods are hard for mortals to recognize' (oủ $\delta$ ' $\tilde{\varepsilon} \gamma v \omega v$ : $\chi \alpha \lambda \varepsilon \pi$ oì $\delta \varepsilon \grave{\varepsilon} \theta \varepsilon$ cò $\theta v \eta \tau o \tilde{\sigma} \sigma v$ ó $\rho \tilde{\alpha} \sigma \theta \alpha 1 ; 111)$; when they enquire who she is, she begins by saying, 'Dear children, whoever of womankind you

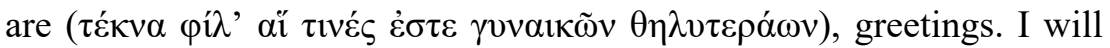
tell you my tale' (119-20). Then she tells the tale of her wanderings, which includes the statement 'then wandering I came here and know

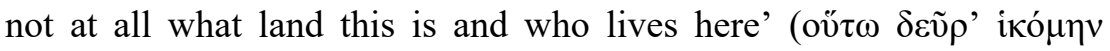

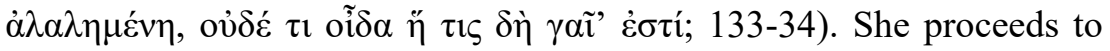
ask, 'Now pity me, maidens, and tell me, dear children, with eager goodwill, whose house I might come to, a man's or a woman's there to do for them gladly such tasks as are done by an elderly woman' (13740). Kallidike replies that she will 'explain these things clearly and name the men to whom great power and honor belong here, who are the first of the people and protect with their counsels and straight judgments the high walls of the city' (150-53). Demeter seems completely clueless: she does not even know who belongs to Eleusis's aristocracy. When Metaneira, the wife of Keleos whose son Demophoön she raises, is shocked when she notices that Demeter buried the boy in the fire during the night, with the purpose of making him immortal, Demeter responds, 'mortals are ignorant and foolish, unable to foresee destiny' (256), without noticing the irony that she had not foreseen that Metaneira would watch her one night. When Demeter changes her size and appearance and thrusts off old age, revealing herself as 'honored Demeter, the greatest source of help and joy to mortals and immortals' (268-69), she demands that the people build her a great temple and follow the rites that she will lay down so that they

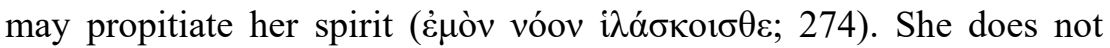
restore joy to Metaneira, who remains voiceless for a long time and forgets her son on the floor. Despite the temple being built, Demeter keeps mourning for her daughter, and provokes a dreadful famine for humankind (304-10), which the gifts of none of the gods can bring to an end (325-34). When Hades is made to release Persephone, who returns to Demeter in Eleusis, Demeter does not know whether her daughter had tasted any food while she dwelt below, an act that would require her to go back to the realm of darkness one third of the seasons

Translation, Commentary, and Interpretive Essays (Princeton: Princeton University Press, 1994), 2-27. The Demeter hymn can be linked with the construction of the Telesterion of Eleusis in the early sixth century BC; cf. W. D. Furley, 'Homeric Hymns', BNP 6, 446. 
(390-404). Again, Demeter is presented as ignorant here of what happened in the underworld. The fact that the Hymn eventually commemorates the subsequent foundation of Demeter's temple and the Eleusinian mysteries illustrates the 'acculturation of epiphany' in Homeric Hymns: while the moments of confrontation by the epiphany of the god 'pose practical, ethical, and interpretative difficulties for their mortal witnesses', the concluding injunctions to found a temple, an altar, a festival or create an image of the god in the god's honour 'serves to frame and domesticate the divinity in an appropriate ritual manner'. ${ }^{15}$

The philosophical version of the self-absorption of the gods removes the gods from such worries as Demeter had. Cicero has Velleius present the Epicurean view of 'the mode of the life of the gods and how they pass their days' as follows:

Their life is the happiest conceivable, and the one most bountifully furnished with all good things. God is entirely inactive (nihil agit) and free from all ties of occupation (nullis occupationibus est inplicatus); he toils not neither does he labour, but he takes delight in his own wisdom and virtue (sua sapientia et virtute gaudet), and knows with absolute certainty that he will always enjoy pleasures at once consummate and everlasting. (Nat.d. 1:51)

\section{Divine Distance}

Despite the anthropomorphism of Homer's gods, the poet knows that gods are dangerous. He pleads for caution when he says 'Gods are dangerous when they manifest themselves clearly' ( $\chi \alpha \lambda \varepsilon \pi \mathrm{oì} \delta \dot{\varepsilon} \theta \varepsilon o i ̀$

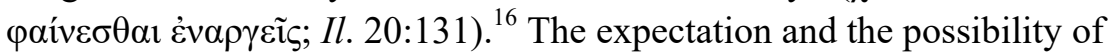

15 Verity Platt, Facing the Gods: Epiphany and Representation in Graeco-Roman Art, Literature and Religion (Greek Culture in the Roman World; Cambridge: Cambridge University Press, 2011), 66.

16 On the term $\chi \alpha \lambda \varepsilon \pi$ oí, which has also been interpreted in the sense that gods are 'difficult' to recognise when they appear to mortals, cf. Richardson, Hymn, 185-86. Cf. Walter Burkert, 'From Epiphany to Cult Statue: Early Greek theos [1997]', in Kleine Schriften VI: Mythica, Ritualia, Religiosa 3, ed. E. Krummen (Göttingen: Vandenhoeck \& Ruprecht, 2011), 139-55, esp. 145 paraphrasing 'gods may even be dangerous and are difficult to behold'. Cf. Walter Burkert, ' $\Theta \mathrm{E} \Omega \mathrm{N}$ OחIN OYK A $\Lambda$ EГONTE $\Sigma$. Götterfurcht und Leumannsches Missverständnis', in Kleine Schriften I: Homerica, ed. C. Riedweg (Göttingen: Vandenhoeck \& Ruprecht, 2001), 93-104, esp. 103, with a critique of Bruno Snell, 'Der Glaube an die olympischen Götter [1942]', in Die Entdeckung des Geistes. Studien zur Entstehung des europäischen Denkens bei den Griechen (orig. 1946; repr. Göttingen: Vandenhoeck \& Ruprecht, 
being punished by the gods is seen in the everyday practice of oaths. ${ }^{17}$ Later critiques of the anthropomorphism of the Homeric gods were provoked by the burlesque of gods seen, for example, in the second song of Demodokos among the Phaiakes, which recounts the adulterous love affair between Ares and Aphrodite and their punishment by Hephaestus (Homer, Od. 8:266-366). The difference between this divine story of adultery and human stories of adultery is the fact that 'for the gods, the confrontation ends without any bloodshed and after the pressure on the part of Poseidon' - what they see as 'no more than a game', ending in laughter, is deadly serious for humans, as for example the quarrel between Agamemnon and Achilles in Iliad 1, which leads to the death of many men. ${ }^{18}$ Apart from the subject of adultery, the song comments on the 'cunning versus force' theme, describing Hephaestus as 'devising evils in the depths of his heart' (8:273), that is, hiding his emotions and planning revenge in silence.

The critique of the concept of anthropomorphic gods is prominently linked with Xenophanes. He rejects the notion of the gods having bodies that can be compared with human bodies:

But mortals suppose that gods are born, wear their own clothes and have

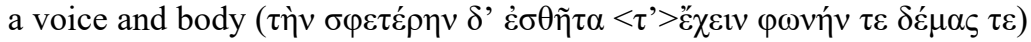
(Frag. 14)

But if horses or oxen or lions had hands or could draw with their hands and accomplish such works as men, horses would draw the figures of the gods as similar to horses, and the oxen as similar to oxen, and they would make the bodies of the sort which each of them had (Frag. 15)

Ethiopians say that their gods are snub-nosed and black; Thracians that theirs are blue-eyed and red-haired (Frag. 16)

In other words, the gods seem to be the product of human beings who depict their gods on the basis of the bodies they have themselves. ${ }^{19}$ Aristotle (384-322 BC) certainly drew this conclusion:

2009), 30-44, esp. 30, who famously argued that in believing in the Olympian gods, they forgot to get the creeps ('die Griechen haben offenbar das Gruseln verlernt').

17 Burkert, Greek Religion, 250-54, esp. 252.

18 Irene de Jong, A Narratological Commentary on the Odyssey (Cambridge: Cambridge University Press, 2001), 207; cf. Walter Burkert, 'Das Lied von Ares und Aphrodite [1960]', in Kleine Schriften I: Homerica, ed. C. Riedweg (Göttingen: Vandenhoeck \& Ruprecht, 2001), 105-16.

19 James H. Lesher, Xenophanes of Colophon. Fragments: A Text and Translation with a Commentary (Phoenix Sup 30; Toronto: University of Toronto Press, 2001), 92- 
Also this explains why all races speak of the gods as ruled by a king, because they themselves too are some of them actually now so ruled and in other cases used to be of old; and as men imagine the gods in human form, so also they suppose their manner of life to be like their own

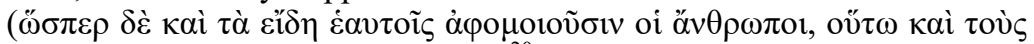

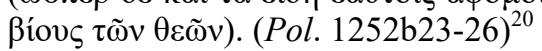

Xenophanes contrasts such religiosity with a discussion of the one god ( $\varepsilon \tilde{i} \varsigma \theta \varepsilon$ śs) who is 'greatest among gods and men, not at all like mortals

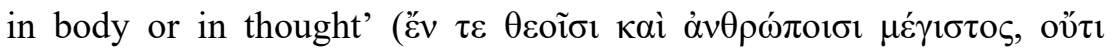

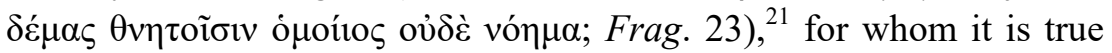

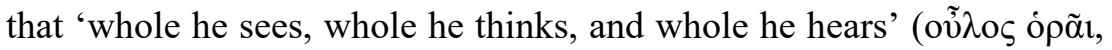

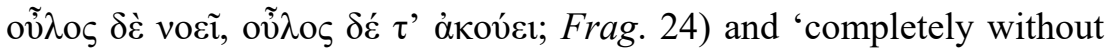

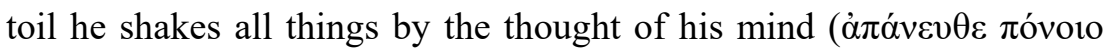

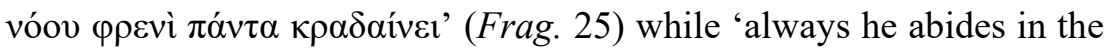
same place, not moving at all, nor is it seemly for him to travel to different places at different times' (Frag. 26). Xenophanes does not say what the greatness of this one god would consist in. He probably thinks of honour or glory and of power (see Homer and Hesiod on Zeus). ${ }^{22}$ For the one god to be the greatest among the gods he has to be fundamentally different from human beings. The phrase 'completely without toil' removes this one greatest god from human beings, and it may be asked how this god can sympathize with, or understand, human beings whose life is toil from beginning to end.

This 'higher criticism' or 'analytical theology' as MacMullen calls it reinterpreted the gods.

The gods really lived; but at a great remove. Cult could not reach them. It might be inoffensive, never persuasive. Mythology, not only as the poets had written it but as the Phrygians embraced Cybele in it, or the

94. Lesher counters the suggestion that Frag. 15-16 constitute ridicule (e.g., Ernst Heitsch, Xenophanes. Die Fragmente [Sammlung Tusculum; München/ürich: Artemis, 1983], 135), noting that Xenophanes does not supply differing views of a single trait rather than four different traits, and pointing to the tolerant acceptance of religious diversity by Herodotus 2.3 (91-92).

20 Harris Rackham, Aristotle: Politics (Aristotle XXI; LCL; Cambridge: Harvard University Press, 1932).

21 Lesher, Xenophanes, 97-99 rejects the interpretation that finds some degree of monotheistic tendencies in Frag. 23 when he asserts that we find 'the novel idea of a single god of unusual power, consciousness, and cosmic influence, but not the stronger view that beyond this one god there could be nothing else worthy of the name' (99). Versnel, Gods, 244-68 argues for a 'double track' understanding of Xenophanes, whose monotheism was not incompatible with polytheistic forms of (cult) religion.

22 Lesher, Xenophanes, 99; cf. Homer, Il. 2.350,412,515; Od. 5.4; 4.515; Hesiod, Theog. 49.534.548. 
Syrians Atargatis, was folly or insult to the true beings above. The sacred had lost its story when its enlightened critics finished with it. But who cared? The inappropriateness of common forms of worship, seen through the eyes of Seneca or Porphyry, appears not to have deterred a single soul from the inheritance of the tribe. ${ }^{2}$

The distance of the gods is rather exuberantly asserted in the hymn written by the prize-winning poet Hermokles of Kyzikos on the occasion of the visit in $290 \mathrm{BC}$ of King Demetrios Poliorketes to Athens. The hymn is preserved by Douris of Samos, and evidently enjoyed wide popularity, as the Athenians sang the hymn both in public and in the home: ${ }^{24}$

See how the greatest and the most beloved gods in our city are present ( $\pi \dot{\alpha} \rho \varepsilon \sigma \tau \imath)$. For here Demeter and Demetrios / one lucky moment brought us. She has come to celebrate the holy mysteries of Kore. Joyous as the god befits, beautiful and laughing, he is present ( $\pi \dot{\alpha} \rho \varepsilon \sigma \tau \imath)$. An august picture is revealed. All friends around him - and he is in the centre. Just as the friends are like the stars, his semblance as the sun is. O son of mighty god Poseidon and Aphrodite, hail you! Now, know that

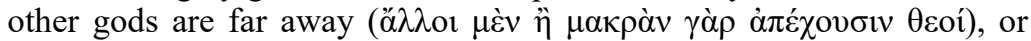

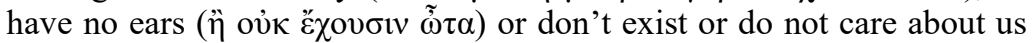

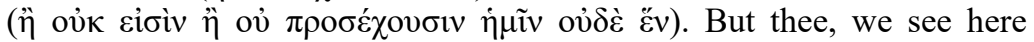
present ( $\sigma \dot{\varepsilon} \delta \dot{\varepsilon} \pi \alpha \rho \rho ́ v \theta$ ' ó $\tilde{\omega} \mu \varepsilon v$ ), not wood, nor stone but real to the bone

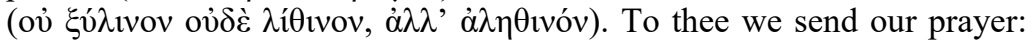
So first of all make peace, most beloved, For thou hast the power (

The next twelve lines consist of a prayer with the request to defeat the Aetolian pirates. The text is an early example of the ruler cult. Noticeable is the emphasis on the presence of Demetrios in contrast to the traditional gods who, with 'fourth-century scepticism', are censured for the absenteeism, for not hearing and not caring, and who may not even exist. ${ }^{26}$

It is a well-known fact that the personal god one finds in Ancient Near Eastern texts has no correspondence in Greek religion as far as the traditional gods are concerned. It is the daimōn who is perceived as

23 Ramsay MacMullen, Paganism in the Roman Empire (orig. 1981; repr. New Haven: Yale University Press, 1983), 77.

24 Ap. Athen. 253F; FGrH II.A Frag. 13, 141-42. For translation and comments cf. Versnel, Gods, 445-46.

25 Douris of Samos, FGrH 76 Frag. 13 ap. Athen. 6.253; translation by Versnel, Gods, 445-46.

26 Versnel, Gods, 449, with reference to Kenneth Scott, 'The Deification of Demetrius Poliorcetes', AJP 49 (1928), 217-39. 
an entity watching over individuals. This is true not only since Heraclitus' reinterpretation of the gods but as early as Pindar, who says: 'I shall honor with my mind whatever fortune (daimōn) attends

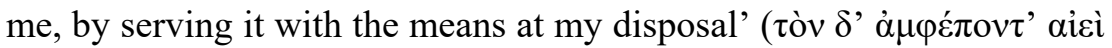

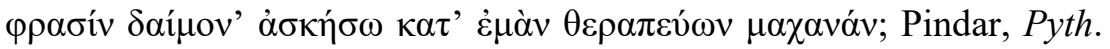
108-109). ${ }^{27}$ Walter Burkert translates: 'Den Daimon, der mich umhegt, will ich stets mit Bewußtsein sorgsam behandeln. ${ }^{28}$ Greeks would often say 'my daimōn', particularly as lament in a situation of misfortune. ${ }^{29}$ The daimōn, in Latin genius, was an intangible power: you cannot come to the daimōn with a request, you cannot control it; it does not leave a human being but it can become very angry. But there is no personal relationship with a god. In Homer, only the gods seem to address themselves with 'dear', thus Zeus addresses Apollo as 'dear Phoebus' ( Philotheos. ${ }^{30}$ But, as Aristotle bluntly states, 'It would be absurd if

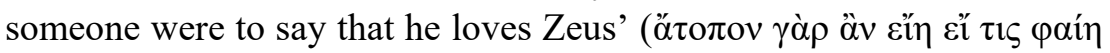

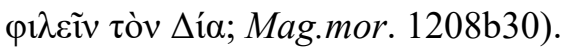

In Cicero's presentation of the Stoic view of the nature of the gods, we find the following sentence: 'The gods attend to great matters; they neglect small ones' (magna di curant, parva neglegunt; Nat. d. 2:167). Cicero infers from the fact that most people use their rational capabilities to do evil:

If therefore the divine intelligence and will displayed care for men's welfare because it bestowed upon them reason, it cared for the welfare of those only to whom it gave virtuous reason (quos bona ratione donavit), whom we see to be very few, if not entirely non-existent ( $s i$ modo ulli sunt esse perpauco). We cannot, however, suppose that the immortal gods have cared for only a few; it follows therefore that they

27 William H. Race, Pindar: Olympian Odes, Pythian Odes (LCL; Cambridge: Harvard University Press, 1997), 262-63.

28 Walter Burkert, 'Mein Gott? Persönliche Frömmigkeit und unverfügbare Götter [1996]', in Kleine Schriften IV: Mythica, Ritualia, Religiosa 1, ed. F. Graf (Göttingen: Vandenhoeck \& Ruprecht, 2011), 225-36, esp. 231 (originally published in Vol. II of the FS Martin Hengel); the following remarks ibid. 231-35; Burkert, Greek Religion, 274-75.

29 Sophocles, Aias 534; El. 1157; Euripides, Alc. 935; Andr. 98; Iph.aul. 1136-37; Med. 1347; Hip. 591; in combination with the Stoic theology of Marcus Aurelius

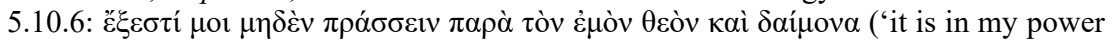
to do nothing contrary to the God and the "genius" within me'; C. R. Haines).

30 Michael J. Osborne and Sean G. Byrne, A Lexicon of Greek Personal Names II: Attica (Oxford: Oxford University Press, 1994), s.v. Пı $\lambda \theta \varepsilon \circ \varepsilon_{\text {; }}$ earliest reference in the fifth century BC. 
have cared for none (sequitur ergo ut nemini consultum sit). (Nat. $d$. $3: 70)$

Cicero notes the objection that the gods gave to human beings the ability to think, and it is the responsibility of people to think and act in righteousness and not do evil, and that the existence of evil cannot be traced back to the gods (3:71-75). He counters this by pointing out that this is as if a physician complains about the severity of the illness or a helmsman about the fierceness of the storm (3:76) and asks 'Do you see then that the verdict of the gods, if they do regard men's fortunes, has destroyed all distinction (between good and evil ) between them?' (videsne igitur deorum iudicio, si vident res humanas, discrimen esse sublatum?; 3:82). The sceptics' position is summarised in the following sentences:

'It (providence) does not care for individuals (non curat singulos homines)'. This is no wonder; no more does it care for cities. Not for these? Not for tribes or nations either. And if it shall appear that it despises even nations, what wonder is it that it has scorned the entire human race? (quid mirum est omne ab ea genus humanum esse contemptum?). (Nat. d. 3:93)

A review of the religious texts of Plutarch (AD 45-120) is instructive. ${ }^{31}$ As far as this Stoic philosopher is concerned, it needs to be stated that even though we have access to religious beliefs and practices through his writings only through the artificial medium of high literature, he was a religious practitioner both officially as priest in Delphi for twenty years and personally as being engaged in religious thought and practice as his description of festivals demonstrates. ${ }^{32}$ He participates willingly because he believes in the presence of the divine in the festival:

Outweighing this a thousand times is the element of cheerful hope, of exultant joy, and whether in prayer or in thanksgiving of ascribing every

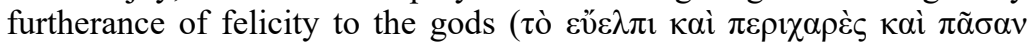

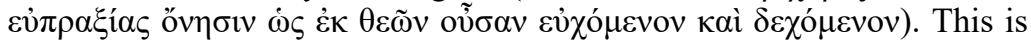
proved by the strongest kind of evidence: no visit delights us more than a visit to a temple; no occasion than a holy day; no act or spectacle than what we see and what we do ourselves in matters that involve the gods,

31 The following remarks rely on Walter Burkert, 'Plutarch: Gelebte Religion und philosophische Theologie [1996]', in Kleine Schriften VIII: Philosophica, eds A. Szlezák and K.-H. Stanzel (Göttingen: Vandenhoeck \& Ruprecht, 2008), 223-39.

32 Plutarch, Suav. viv. 1100E-1101E; Num. 8; Superst. 169D. 
whether we celebrate a ritual or take part in a choral dance or attend a sacrifice or ceremony of initiation. (Plutarch, Suav. viv. 1101E) ${ }^{33}$

At the same time, Plutarch points out that without the presence of the god in the festival the priest who sacrifices is but a butcher and the worshipper goes away 'with Menander's words on his lips: "I

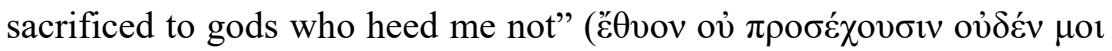

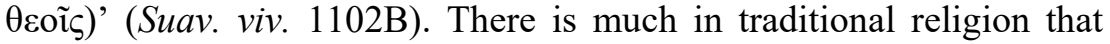
Plutarch does not understand or does not like: this he calls 'superstition' ( $\delta \varepsilon 1 \sigma 1 \delta \alpha 1 \mu \mathrm{ovi} \alpha)$. The very essence of superstition is fear of the gods:

Superstition, as the very name (dread of deities) indicates, is an emotional idea and an assumption productive of fear which utterly humbles and crushes a man, for he thinks that there are gods, but that they are the cause of pain and injury ... superstition is a multitude of

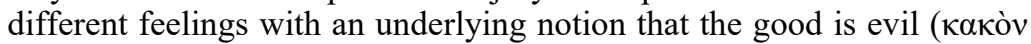

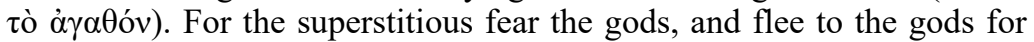
help; they flatter them and assail them with abuse, pray to them and blame them ... every disposition of his body, loss of property, deaths of children, or mishaps and failures in public life are classed as 'afflictions of God' ( $\pi \lambda \eta \gamma \alpha i$ i $\theta \varepsilon 0 \tilde{)})$ or 'attacks of an evil spirit' ( $\pi \rho \circ \sigma \beta 0 \lambda \alpha$ ì

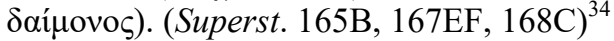

In the context of both Old and New Testament passages about God knowing people, this position seems to imply for Plutarch that either the behaviour of people is irrelevant for true worship or that the gods do not punish human beings. In fact, he asserts that philosophers and statesmen

try to prove that the majesty of God is associated with goodness,

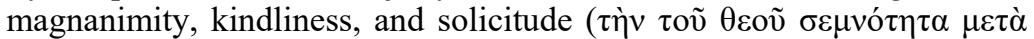

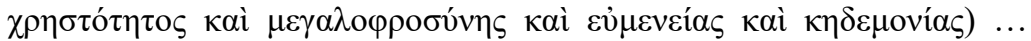

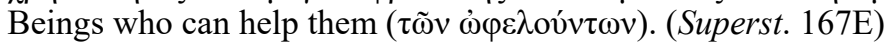

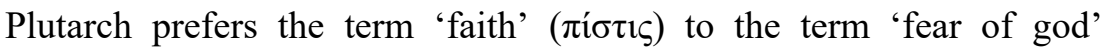
$(\theta \varepsilon 0 \sigma \varepsilon \dot{\beta \varepsilon} \varepsilon \alpha)$, with pistis being grounded in ancestral tradition (Superst.

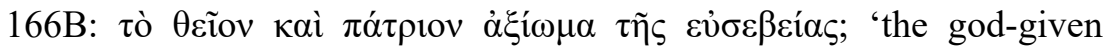
ancestral dignity of our religion'). This is the same position as that argued for by the sceptic Cotta in Cicero's De deorum natura. Plutarch

33 Cf. Plutarch, Suav. viv. 1103DE. Phillip H. de Lacy and Benedict Einarson, Plutarch. Non posse suaviter vivi secundum Epicurum (LCL; Moralia XIV; Cambridge, Massachusetts: Harvard University Press, 1967).

34 Frank Cole Babbitt, Plutarch. De superstitione (orig. 1928; repr. Moralia II; Cambridge: Harvard University Press, 1971). 
does not report on specific revelations of a god: the conviction that they are present during sacrifice is a postulate, not a matter of observable evidence. Despite observations on foreign religions in Quaetiones romanae et graecae or in de Iside et Osiride, which demonstrate his curiosity, Burkert asserts that 'the distance remains: the divine cannot be experienced directly'. ${ }^{35}$ As regards the mysteries, Plutarch states in De defectu oraculorum:

Regarding the rites of the Mysteries, in which it is possible to gain the

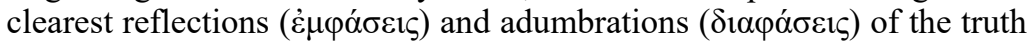
about the demigods ( $\pi \varepsilon \rho i$ $\delta \alpha \mu o ́ v \omega v ~ \dot{\alpha} \lambda \eta \theta \varepsilon i ́ \alpha \varsigma)$, "let my lips be piously sealed,' as Herodotus says. (Def. orac. 417C) $)^{36}$

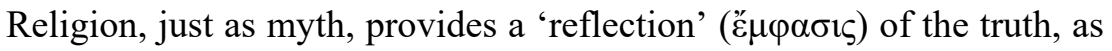
the rainbow (Isa. Os. 359A). Since non-disclosure of the ritual of initiation, which distinguished the mysteries from the public domain, was fundamental, resulting in the fact that we have no literary texts that describe what happened, we do not know how and in what sense the 'emotional experiences in which a feeling of closeness to the divine was the ultimate goal of the initiate ${ }^{37}$ was achieved and what it looked like. Religious rites allow us a 'seeing through' ( $\delta$ ió $\varphi \alpha \sigma \iota \varsigma)$, as seeing through a curtain or dulled glass - and he speaks only of the daimones, not of the gods. Despite the fact that he was a priest in Delphi for two decades, Plutarch emphasises both the divine origin and the indirect nature of Apollo's speaking to human beings: it remains even unclear whether the god's thoughts are communicated through Pythia. He writes,

I imagine that you are familiar with the saying found in Heracleitus to the effect that the Lord whose prophetic shrine is at Delphi neither tells

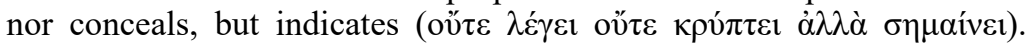
Add to these words, which are so well said, the thought that the god of this place employs the prophetic priestess for men's ears just as the sun

35 Burkert, 'Plutarch', 230: 'die Distanz bleibt: Das Göttliche wird nicht direkt erlebbar'.

36 Frank Cole Babbitt, Plutarch. De defectu oraculorum (orig. 1936; repr. Moralia V; Cambridge: Harvard University Press, 1993).

37 Lucinda Dirven, 'The Mithraeum as tableau vivant: A Preliminary Study of Ritual Performance and Emotional Involvement in Ancient Mystery Cults', Religion in the Roman Empire 1 (2015), 20-50, esp. 21, with reference to Katharina Waldner, 'Dimensions of Individuality in Ancient Mystery Cults: Religious Practice and Philosophical Discourse', in The Individual in the Religions of the Ancient Mediterranean, ed. J. Rüpke (Oxford: Oxford University Press, 2013), 215-42, esp. 226. 
employs the moon for men's eyes. For he makes known and reveals his

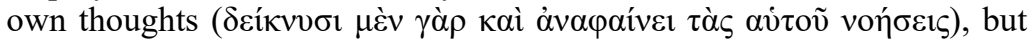

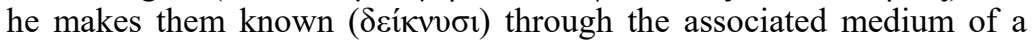
mortal body and a soul that is unable to keep quiet, or, as it yields itself to the One that moves it, to remain of itself unmoved and tranquil, but, as though tossed amid billows and enmeshed in the stirrings and emotions within itself, it makes itself more and more restless. (Def. orac. 404E)

Plutarch discusses the theory that daimones speak through Pythia, or that a pneuma rising up from the earth mediates divine reality, and tries to find a way to link the divine and the material in the body and the soul of Pythia. These remain hypotheses, which do not lead to the certainty of faith. The account of a 'bad trip' of a particular session during which Pythia starts to scream, leaving her eventually dead, leads Plutarch to the conclusion:

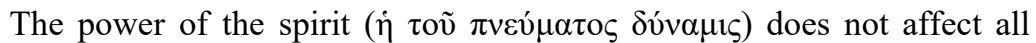
persons nor the same persons always in the same way ... The power

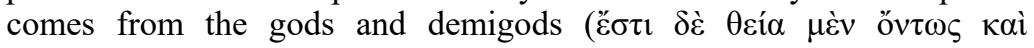
$\delta \alpha \mu v_{v i o s}$ ), but, for all that, it is not unfailing nor imperishable nor ageless, lasting into that infinite time by which all things between earth and moon become wearied out, according to our reasoning. And there are some who assert that the things above the moon also do not abide, but give out as they confront the everlasting and infinite, and undergo continual transmutations and rebirths. (Def. orac. 438D)

The commitment to tradition, not the least in the face of death, leads Plutarch to the telling statement in Consolatio ad uxorem regarding the fate of those who departed to a dispensation and a region that is better and more divine: 'This is harder to disbelieve than to believe' ( $\tau$ ò

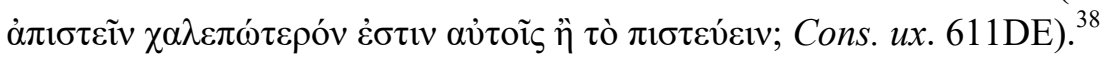

\section{Divine Care for People}

The texts about the gods' distance are literary texts, written by philosophers, a minority that is never representative of a society. If the gods would have been regarded as distant by all people, it would be difficult to explain the countless temples, shrines, and statues and figurines of deities that have been discovered. Ramsay MacMullen, who calls Plutarch's approach 'bookish in the extreme, and in a sense

38 Phillip H. de Lacy and Benedict Einarson, Plutarch. Consolatio ad uxorem (LCL; Moralia VII; Cambridge, Massachusetts: Harvard University Press, 1959). 
also extremely rational', has discussed the relevant evidence that demonstrates the vitality of paganism. ${ }^{39}$ Ovid (43 BC-17 AD) expresses the closeness of Vesta, and of the deity more generally, in these words:

Vesta, be gracious! To you we now open our lips for worship - if indeed we may join your ceremonies. I was completely absorbed in prayer (in prece totus eram), I was aware of the divine powers; and the earth, joyful, shone back with a dark red glow (aetaque purpurea luce refulsit humus). (Ovid, Fasti 6:249-52)

Dio Chrysostom (AD 40/50-110/120) similarly states:

All men feel a powerful longing to honor deity and pay cult from close

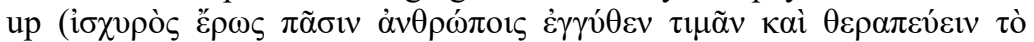
$\theta \varepsilon \tilde{c}$ v), drawing near and seizing hold with persuasion, offering sacrifices and crowning with wreaths. Just as tiny children, torn away from father or mother, feel a terrible longing and desire, and often reach out their hands in their very dreams to the absent ones, so to the gods,

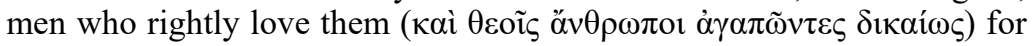
their beneficence and kinship are eager to be and to talk with them by any means. (Dio Chrysostom, Or. 12:60-61) ${ }^{40}$

Communication with the gods is a central feature of Greek hymns, which reflect Greek and Roman religiosity much more directly than literary or philosophical texts. William Furley and Jan Bremer state:

In many hymns the rhetoric of the text works on two different levels (or channels) of communication. In every hymn there is always the internal communication addressed by the worshipping mortal(s) to the god. But in many cases there is also external communication between the poet and/or the performers and the audience. ${ }^{41}$

Personal contact with the god is a key feature of Callimachus's orchestration of the gods as conversation partners in his hymns, often using the second person singular for the members of the community addressing the god. Callimachus (born between 320-303 BC) not only praises the gods, following a long-established tradition, but he also asks questions, creating the impression that he asks them for information and indeed that he receives an answer. The last point is a third level of

39 MacMullen, Paganism, 62-73 and passim; quotation 69. He cites ibid. 71 the summary of P. Parsons in The Oxyrhynchus Papyri XLII (1973), 30, n.1 of the text P. Oxy. XLII 3008 as follows: 'Philosophers agree about nothing - one of them even says that silver is black. You can hear more uproar from a household of philosophers than from a household of madmen.'

40 Both quotations from MacMullen, Paganism, 63-64.

41 Furley and Bremer, Greek Hymns, vol. 1, 59. 
communication: the implicit communication of the god with the poet. ${ }^{42}$ In Callimachus' Hymn to Artemis, the speaker addresses Artemis thus: 'You must tell me that, goddess, and I shall sing about it to the others'

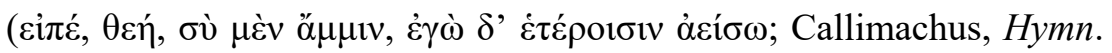
Artemis 186). ${ }^{43}$

City gods are beholden to their polis. Artemis is often mentioned as patron deity of cities in Asia Minor, probably as a result of her role in the cities of the Doric and Ionian colonisation. ${ }^{44}$ In the Homeric Hymn to Aphrodite, Artemis is described as follows:

Nor does smile-loving Aphrodite ever overpower Artemis of the gold arrow-shafts and loud cries with love ( $\dot{\varepsilon} v \varphi \imath \lambda o ́ \tau \eta \tau \imath)$; for she is interested (Évaípevv) in bows and in killing wild animals in the mountains, and in lyres, dances, shrill hosannahs, shady sacred groves, and the city of just men. (Hom. Hymn. Aphrod. 5:16-20)

Anakreon entreats Artemis Leukophryene, the main goddess of Magnesia on the Maeander, to care for the citizens:

I appeal to you, fair-haired, deer-shooting daughter of Zeus, Artemis, queen of game: with pleasure, surely, now you look upon ( $\chi \alpha$ ípovo') the valiant population of the town by the river Lethaios, for the citizens in your flock are anything but uncouth. (Frag. 348)

Patricia Rosenmeyer calls this text 'a curiously personal prayer on behalf of the Magnesian citizens'. ${ }^{47}$ Ivana Petrovic emphasises the

42 Ivana Petrovic, Von den Toren des Hades zu den Hallen des Olymp. Artemiskult bei Theokrit und Kallimachos (Mnemosyne Supplementa 281; Leiden/Boston: Brill, 2007), 145. In Callimachus's Hymn to Artemis, we have second-person narration in 72-190, and brief 'dialogues' in which the speaker asks for information: a series of three questions and answers in 113-135, where only the first answer may be attributed to Artemis; cf. M. Annette Harder, 'Callimachus', in Narrators, Narratees, and Narratives in Ancient Greek Literature, eds I. J. F. de Jong, R. Nünlist, and A. Bowie (Studies in Ancient Greek Narrative 1; Mnemosyne Sup; Leiden: Brill, 2004), 63-81, esp. 65.

43 Translation from Harder, 'Callimachus', 65.

44 Erika Simon, Die Götter der Griechen (Vierte Auflage; orig. 1985; repr. München: Hirmen, 1998), 154-55; Petrovic, Artemiskult, 205-207.

45 S. Douglas Olson, The Homeric Hymn to Aphrodite and Related Texts. Text, Translation and Commentary (Berlin: De Gruyter, 2012), 59.

46 Furley and Bremer, Greek Hymns, vol. 1, 178. Cf. Franyö Zoltan and Bruno Snell, Frühgriechische Lyriker III: Sappho, Alkaios, Anakreon (Berlin: Akademie-Verlag,

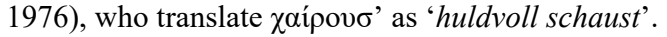

47 Patricia A. Rosenmeyer, The Poetics of Imitation: Anacreon and the Anacreontic Tradition (Cambridge: Cambridge University Press, 1992), 37. 
political context of this role of Artemis. ${ }^{48}$ The 'love' of Artemis for the citizens of the polis who worship her as patron deity is not a personal love for individuals, but her care for the political order. A similar claim of giving cities political order is made for Demeter in Callimachus' hymn to the goddess:

Rather, (let us speak) of how she bestowed fair laws on cities ( $\dot{\omega} \varsigma$

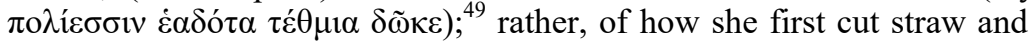
handfuls of corn-ears and set oxen to thresh them ... The Pelasgians still inhabited holy Dotium, not yet the Cnidian land; there (?) they had built a fair grove thick with trees - an arrow could hardly have passed through. Within were pines, large elms, and pear-trees, and fair sweetapples; and the amber-coloured water boiled up from ditches. Demeter was madly fond of the place $\left(\theta \varepsilon \dot{\alpha} \delta^{\prime} \dot{\varepsilon} \pi \varepsilon \mu \alpha i v \varepsilon \tau o ~ \chi \omega ́ \rho \omega\right)$ as of Eleusis, as fond of Triopas as she was of Enna. (Callimachus, Hymn. Demeter 1819, 24-30; N. Hopkinson) $)^{50}$

The second refrain of each of the twelve stanzas in Philodamos's paian to Dionysos repeat the same one-line acclamation (epiphthegma) and two-line prayer in aeolo-choriambic rhythm: ${ }^{51}$

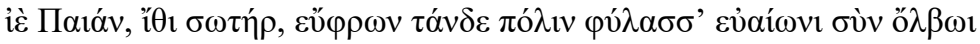
Ie Paian, come o Savior, and kindly keep this city in happy prosperity

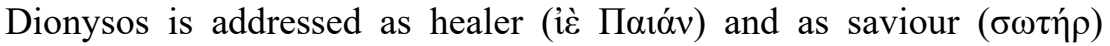
formally for the first time in this hymn; generally it is Apollo and/or his son Asklepios who is addressed as healer, and Zeus as saviour. We see in Euripides that some worshippers viewed Dionysos as healing pain and as saviour, and Sophocles has the Thebans state that since their city is ravaged by disease (vóøov) Dionysos should come and bring

48 Petrovic, Artemiskult, 205: 'diejenige, unter deren Obhut alle wichtige Angelegenheiten einer Stadt—vor allem die politische Ordnung — stehen'.

49 Neil Hopkinson, Callimachus: Hymn to Demeter. Edited with an Introduction and Commentary (Cambridge Classical Texts and Commentaries 27; Cambridge:

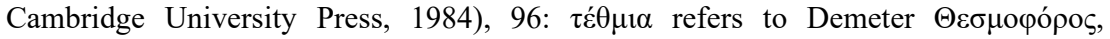
"supposedly so-called either because she "set up" laws after introducing agriculture (Macrob. Sat. 3.12) or because inscribed bronze tablets recording the law were "set up" in her temple'.

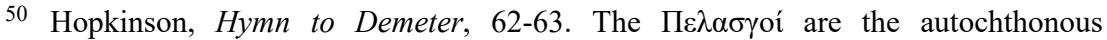
inhabitants of Thessaly.

51 Henri Weil, 'Un péan delphique à Dionysos', $B C H$ 19, 21 (1897), 343-418, 510-13; cf. Furley and Bremer, Greek Hymns, vol. 1, 121-23; vol. 2, 52-57. The paian is dated to $340 / \mathrm{BC}$ (ibid 1:124-26). 
healing. ${ }^{52}$ The patron god of a city is supposed to guard the city

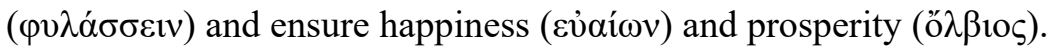

The gods were also invoked as protectors of the city in drinking songs (skolia), as several examples from Athens demonstrate: ${ }^{53}$

Pallas, Triton-born, Lady Athena preserve this city and its inhabitants free of troubles and civic strife and premature deaths: you and your father

Mother of Wealth, Olympian Demeter among the garlanded Seasons I sing, and you, daughter of Zeus,

Persephone; and pray: protect this city carefully!

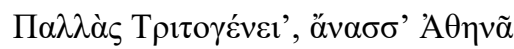

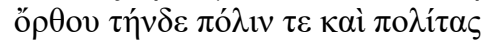

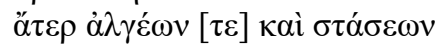

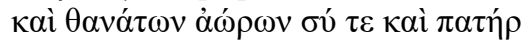

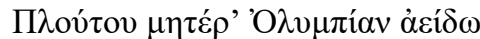

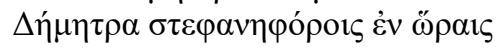

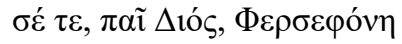

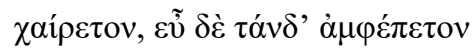
$\pi$ ó̀ıv

In the first song, the term ob $\rho$ ov has a general meaning ('maintain', 'keep'), combining the ideas of continuity and prosperity; in line 4, Zeus is introduced 'almost as an afterthought, but an important one' as the Olympian gods are invoked 'to act in unison, not independently'. ${ }^{54}$ In the second song, the prayer 'protect this city carefully' uses the verb $\dot{\alpha} \mu \varphi \varepsilon ́ \pi \omega$, which is 'a favourite verb of hymnodists to describe the care and nurture they wish to procure from a god'. ${ }^{55}$

\section{Divine Knowledge and Personal Benefit}

Arguably, the most important factor in communicating with the gods was a benefit of some kind. The Themistocles Decree (481/480 BC)

52 Euripides, Bacch. 772 and 576-603,862-76; Sophocles, Ant. 1140-41. For commentary cf. Furley and Bremer, Greek Hymns, vol. 2, 63.

53 Denys L. Page, Poetae Melici Graeci (Oxford: Clarendon, 1962), 884,885; Elena Fabbro, I carmi conviviali attici. Introduzione, testimonianze, testo critico, traduzione e commento (Lyricorum Graecorum quae exstant 11; Rome: Istituti editoriali e poligrafici internazionali, 1995), no. 1, 2; Furley and Bremer, Greek Hymns, vol. 1, 259; vol. 2, 214-17.

54 Furley and Bremer, Greek Hymns, vol. 2, 215.

55 Furley and Bremer, Greek Hymns, vol. 2, 217; cf. ibid vol. 1, 54-55 on the importance of the god's location, which often occurs in invocations. Furley and comment: 'In contrast to the god of Christianity whose cosmic omnipresence is fundamental, Greek gods are related to specific locations ... Gods are immortal and enjoy freedom to appear when and where they like. But a god was born at a specific spot ... or first stepped on land there, has her/original sanctuary there ... or the location is in some other way the god's personal domain, area of power' (54). 
begins with the sentence 'The city shall be entrusted to Athena who guards Athens, and to the other gods, all of them, for protection and defense against the barbarian on behalf of the country. ${ }^{56}$ One of the very few instances where the phrase 'my god' is used in Greek texts is the collective of the chorus in Euripides stating, upon seeing the sculptures of the temple in Delphi, 'I see Pallas, my goddess' ( $\lambda \varepsilon v$ $\sigma \sigma \omega$

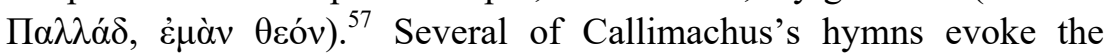
epiphany of the deity who is expected to protect the city. In the Hymn to Zeus, the god is described in this role:

You gave them cities to guard, and sat yourself in their cities' high

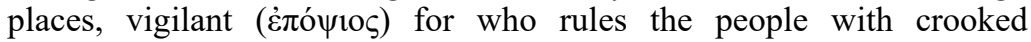

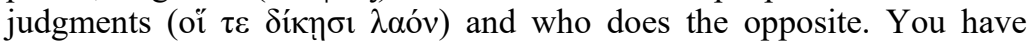
bestowed wealth on them, and abundant prosperity to all, but not very evenly (ov̉ $\mu \alpha \dot{\lambda} \alpha \alpha$ ' $\tilde{\delta}^{\text {ĩ }} \sigma \mathrm{ov}$ ). (Callimachus, Hymn. Zeus 80-85)

The last lines of the Hymn to Demeter read:

Hail, goddess, and save this city ( $\sigma \alpha \dot{\omega} \omega \pi \operatorname{\lambda } \imath v$ ) in concord and prosperity, and produce a good return in the fields: feed our cattle, bring forth fruits and crops, bring the harvest and nourish peace, so that he who has sown may reap. Be favorable to me (ỉ $\lambda \alpha \theta i$ $\mu \mathrm{ot}$ ), thrice-invoked, most powerful of goddesses. (Callimachus, Hymn. Demeter 134-38)

The soteriological epiphany motif ${ }^{59}$ of the hymn invokes the presence of the goddess who is expected to protect the political order and thus the prosperity of the polis and her citizens. In Callimachus's hymns, the gods 'are on constant alert and more active than gods in other Greek religious poetry ${ }^{60}$ Callimachus uses various strategies in order

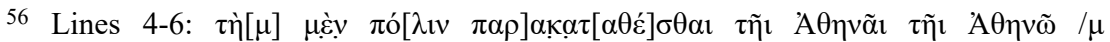

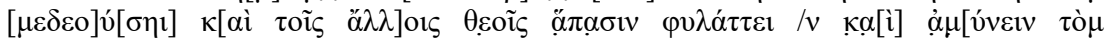

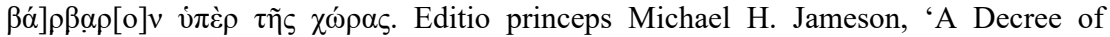
Themistocles from Troizen', Hesperia 29 (1960), 198-223 (text 199-200, translation 200-201). See SEG XXIV 276; XXV, 376; XXX 384. Translation from Russel Meiggs and David M. Lewis, A Selection of Greek Historical Inscriptions to the End of the Fifth Century B.C. (rev. ed.; orig. 1969; repr. Oxford: Clarendon, 1988), 48-52 (no. 23).

57 Euripides, Ion 211 (D. Kovacs).

58 Susan A. Stephens, Callimachus: The Hymns. With Introduction, Translation, and Commentary (Oxford: Oxford University Press, 2015), 54,56.

59 Petrovic, Artemiskult, 142-43.

60 Albert Henrichs, 'Gods in Action: The Poetics of Divine Performance in the Hymns of Callimachus', in Callimachus, eds M. A. Harder, R. F. Regtuit, and C. G. Wakker (Hellenistica Groningana 1, Proceedings of the Groningen Workshop on Hellenistisc Poetry; Groningen: Forsten, 1993), 127-47, esp. 127; the following remark ibid. 14143; also Petrovic, Artemiskult, 150-51. 
to convey the impression of divine activity, particularly the depiction of the emotions of the gods, their body parts, and their actions, rendering them visually imaginable and creating the impression that they are moving. Ivana Petrovic explains the soteriological epiphanies of the Hellenistic period - a time in which gods and soon rulers were called Soter and Epiphanes - with the desire to experience the deity as close. ${ }^{61} \mathrm{I}$ do not see that 'knowing' the citizens of a polis, or an individual, on the part of one of the gods plays any role.

When previous experiences with the god are invoked, the god seems to know what the person contacting him wants. The first poem of Sappho's extant fragments (seventh/sixth century BC) is a case in point. The 'I' calls on Aphrodite to help her in a love affair:

Shimmering, iridescent, deathless Aphrodite, child of Zeus, weaver of wiles, I beg you, do not crush my spirit with anguish, Lady, but come now, if ever before you heard my voice in the distance and leaving your father's golden house drove your chariot pulled by sparrows swift and beautiful over the black earth, their wings a blur as they streaked down from heaven across the bright sky - and then you were with me, a smile playing around your immortal lips as you asked, what is it this time? why are you calling again? And asked what my heart in its lovesick raving most wanted to happen: 'Whom now should I persuade to love you? Who is wronging you, Sappho? She may run now, but she'll be chasing soon. She may spurn gifts, but soon she'll be giving. She may not love now, but soon she will, willing or not.' Come to me again now, release me from my agony, fulfil all that my heart desires, and fight for me, fight at my side, Goddess. (Sappho, Poem 1$)^{62}$

The speaker of the poem invokes a previous event of divine charis and visualises Aphrodite's grace being conveyed in a personal epiphany, complete with a journey from Zeus's palace in a winged chariot, meeting her on earth with a smile on her lips. The evocation of the past, intended to promote the reappearance of the goddess, 'is a form of verbal flattery designed to entice the goddess'. ${ }^{63}$ The speaker knows her sexual needs; she invokes the goddess with the argument that she knows these needs as well from a previous encounter and with the plea to help her get what she wants.

61 Petrovic, Artemiskult, 153-70.

62 Stanley Lombardo, Sappho: Poems and Fragments (Indianapolis: Hackett, 2002), 5.

63 William D. Furley, 'Prayers and Hymns', in A Companion to Greek Religion, ed. D. Ogden (Chichester: Blackwell, 2007), 117-31, esp. 126; Furley and Bremer, Greek Hymns, vol. 1, 97 speak of 'advent myths'. 
It is beneath the dignity of Zeus to be described as loving human beings: 'this qualification is left for Prometheus or Hermes, at best'. ${ }^{64}$ Aristophanes (c. 445-385 BC) writes

Don't be so hostile to our entreaties as to prevent our getting her; but be gracious, most philanthropic of divinities and most bountiful $(\tilde{\omega}$

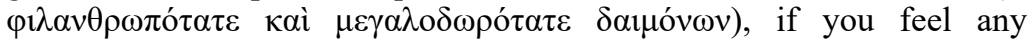
loathing for Pisander's crests and brows, and we will always, Lord, pay you homage continually with holy sacrifices and great processions. (Aristophanes, Pax 390-99) ${ }^{65}$

The context is again collective, communal, not personal, an aesthetic 'aha experience'. ${ }^{66}$ In the confession inscriptions of Maeonia, we often find the name of the authochthonos god Men linked with a personal name added in the genitive, e.g. 'Men of Artemidoros' (Mìv A $\tau \tau \mu \mu 1 \delta \dot{\omega} \rho 0 v)$ or 'Men of Pharnakes', where the persons mentioned are seeking or have experienced healing. ${ }^{67}$ The person praying expects a benefit, a personal connection with the god is not assumed. ${ }^{68}$ One inscription states, after giving the date (the twelfth of the month Panemos in the year 320, i.e. AD 235/236),

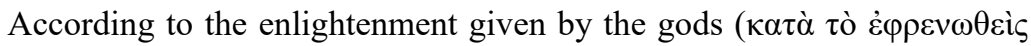
vंđò $\tau \tilde{\omega} v \theta \varepsilon \tilde{\omega} v$ ), by Zeus and the great Men Artemidorou: 'I have punished Theodorus in respect to his eyes in consequence of the sins which he committed. ${ }^{69}$

The 'knowledge' of the god pertains to particular sins that Theodorus has committed: in the next lines of the long inscription three occasions of sexual misbehavior are given, complete with the punishment meted out by the gods. The fact that the body part that was affected by the anger of the god, in this case a pair of eyes, is incised on the stone that carries the inscription may be due to the fact that either the god or the community, or both, needed to be reminded of where exactly the

64 Burkert, Greek Religion, 274.

65 Jeffrey Henderson, Aristophanes. Clouds. Wasps. Peace (LCL; Aristophanes II; Cambridge: Harvard University Press, 1998). For Prometheus see Aeschylus, Prom. 11,28 .

66 Burkert, 'Mein Gott', 234.

67 Eugene N. Lane, Corpus Monumentorum Religionis Dei Menis (EPRO 19.1-4; Leiden: Brill, 1971-1978), vol. 3, 67-70.

68 Burkert, 'Mein Gott', 235.

69 Hasan Malay, 'New Confession-Inscriptions in the Manisa and Bergama Museums', EA 12 (1988), 147-52, esp. 151-52 (no. 5, lines 1-2); Petzl, Beichtinschriften Westkleinasiens, no. 11. On the verb translated by Malay as 'enlightenment given', LSJ s.v. $\varphi \rho \varepsilon v o ́ \omega$ I 'make wise, instruct, inform'. 
healing needs to take place. The non-Greek character of the confession inscriptions is noted by many scholars. ${ }^{70}$ The 'rule of the gods' expressed by these inscriptions ${ }^{71}$ may be the result of priests of the local sanctuaries using the practice of public humiliation and confession 'to further the exaltation of the local gods, thus preventing the people from seeking the forgiveness of sins elsewhere', e.g. in the Christian churches. ${ }^{72}$ The benefit that the people who confess their sins in public seems to be mostly accruing to the god of the local sanctuary with which the steles were connected.

It is instructive in the context of seeking favour from the gods that Simon Pulleyn distinguishes Greek prayers on a descending scale depending on how much charis the person who prays thinks he or she has with the god(s): Gevía (xenia; 'friendship') prayers draw on a

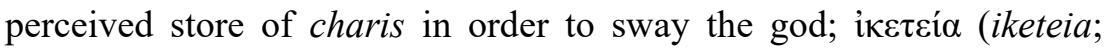
'supplication') prayers are at the bottom of the scale, with the person praying feeling that he or she has no amount of credit with the god and thus has to throw him or herself upon the mercy of the god; $\lambda \iota \tau \alpha i$ (litai; 'prayers') occupy the middle position. ${ }^{73}$

Dio Chrysostom insists, as do other writers, that the essential nature of the divine is goodness, in the sense of active beneficence in all areas of life.

70 Josef Zingerle, 'Heiliges Recht', Jahreshefte des Österreichischen Archäologischen Instituts. Beiblatt 23/(1926/), 8-72,-24,48-49; Raffaele Pettazzoni, Essays on the History of Religions (Studies in the History of Religions 1; Leiden: Brill, 1954), 55-67; Hendrik S. Versnel, 'Sin', OCD, 4th ed. (2012), 1371; Peter Frisch, 'Über die lydischphrygischen Sühneinschriften und die 'Confessiones' des Augustinus', EA 2 (1983), 41-45; Marijana Ricl, 'CIG 4142: A Forgotten Confession-Inscription from North-West Phrygia', EA 29 (1997), 35-43, esp. 36-37; Stephen Mitchell, 'The Cult of Theos Hypsistos between Pagans, Jews, and Christians', in Pagan Monotheism in Late Antiquity, eds P. Athanassiadi and M. Frede ( Oxford: Clarendon, 1999), 81148, esp. 112,114.

71 Stephen Mitchell, Anatolia: Land, Men, and Gods in Asia Minor, 2 vols (Oxford: Oxford University Press, 1995), vol. 1, 191.

72 Eckhard J. Schnabel, 'Divine Tyranny and Public Humiliation: A Suggestion for the Interpretation of the Lydian and Phrygian Confession Inscriptions', NovT 45 (2003), 160-88, esp. 187.

73 Simon Pulleyn, Prayer in Greek Religion (Oxford Classical Monographs; Oxford:

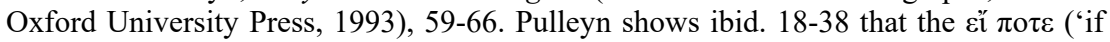
ever'; da quia dedi [give because I gave]) mentality is a specifically Greek phenomenon for which it is 'not easy to adduce convincing parallels' (18), and that it 'existed in real life' (37). The constituent parts of a Greek prayer are invocation, argument (the petitioner adduces reasons why his request should be granted), and request; cf. ibid. 132-55; Furley, 'Prayers and Hymns', 122. 
And first of all - to begin, as I ought, with matters close at hand - rest assured of this, that all things which happen to men for their good are

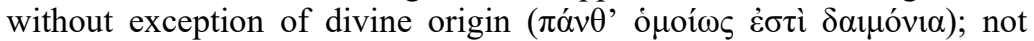
only is this true if a voyager has the luck to find a pilot with experience, or a nation or a city to secure good leaders, but also if a physician arrives in time to save his patient, we must believe that he is a helper come from god, and if one hears words of wisdom, we must believe that they too were sent by god. For, in general, there is no good fortune, no benefit

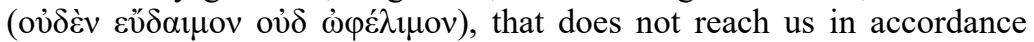

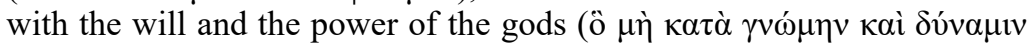
$\tau \tilde{\omega} v \theta \varepsilon \tilde{\omega} v)$; on the contrary the gods themselves control all blessings everywhere and apportion lavishly to all who are ready to receive

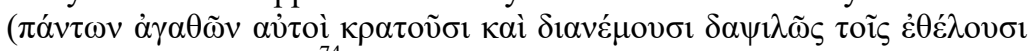
$\delta \varepsilon ́ \chi \varepsilon \sigma \theta \alpha \mathrm{\imath}) .(\operatorname{Or} .36: 15)^{74}$

In his discussion of the nature of the gods, Cicero portrays the sceptics' position regarding the origin of virtue with a view to what people want from the gods:

But this is the way with all mortals: their external goods, their vineyards, cornfields and olive-yards, with their abundant harvests and fruits, and in short all the comfort and prosperity of their lives, they think of as coming to them from the gods ( $a$ dis se habere); but virtue no one ever imputed to a god's bounty ... The reason why men give to Jupiter the titles of Best and Greatest is not that they think that he makes us just, temperate or wise, but safe, secure, wealthy and opulent (sed quod salvos incolumis opulentos copiosos). (Nat. d. 3:86, 878-88)

Cicero regularly invoked the gods in his speeches, characterising opponents such as Clodius as 'the enemy of the gods', claiming allegiance of the gods for himself in an attempt to win an argument and promote his political goals. His political enemies argued within the same religious consensus and claimed the loyalty of the gods for themselves. The question 'was not whether the gods were perceived to co-operate with the political leaders of Rome; but with which political leaders was their favour placed? ${ }^{, 75}$ The implicit claim to know the gods and their pleasure served the promotion of political advantage.

In a second-century hymn to Telesphoros, the gnome-like figure dressed in a hooded cape and sitting at the feet of Asklepios in

74 James W. Cohoon, Dio Chrysostom. Discourses 31-36 (orig. 1940; repr. LCL; Dio Chrysostom III; Cambridge, Massachusetts: Harvard University Press, 1979).

75 Mary Beard, John North, and Simon Price, Religions of Rome (Cambridge: Cambridge University Press, 1998), 140, who point to the analogous tactics of Saturninus and Catiline. 
Epidaurian iconography, Telesphoros is addressed as 'all-knowing,

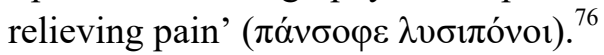

\section{Conclusions}

Concepts of belonging to God, being chosen by God, and being a child of God, which we find in connection with the phrase 'known by God' in biblical tradition, ${ }^{77}$ are not completely alien in the Greek and Hellenistic world. However, our survey of the concept of knowing the divine and of divine knowledge has shown that Greeks and Romans believed that it is difficult to know the gods, a conviction that is often stated and even more often implied. This is true even in the context of oracles, which are believed to represent a communication of a god to human beings, since the oracles' origin and reliability are not certain, at least not for the higher critics. The essential self-absorption of the gods focuses their attention on themselves rather than on human beings. If a god, for example Zeus, is deemed powerful or even omnipotent, his omniscience, when it is claimed, does not mean that he is interested in human beings or knows the people who pray to him. The power of the gods is arbitrary and unpredictable, and their omniscience is general, not personal. While in the biblical tradition the people of God may voice their lack of understanding as to why God acts in a certain way or does not act at all (see Eccl., Job), they know that they can entrust the present reality of their lives and their future to God because he is their Father who knows them and who cares for them. A climactic example is Jesus' prayer in Gethsemane.

The arbitrariness of the omnipotence and omniscience of the gods created the perception of divine distance. People experience the gods in cults, in festivals and in processions, but communication with them generally requires mediators, such as priests, dreams or oracles. Some people seem to have had a personal experience of a god, reflected in the active and joyful engagement in the worship of a particular god or of several gods. How that experience compared on an emotional level with the experience of Israelites, Jews, and Christians who asserted that they live in communion with Yahweh, the God of Abraham, Isaac,

76 IG III.i 171; Furley and Bremer, Greek Hymns, vol. 1, 268-69; vol. 2, 235.

77 Rosner, 'Known by God', 206-19. R. Bultmann's article on $\gamma 1 v \omega ́ \sigma \kappa \omega / \varepsilon ̇ \pi \imath \imath v \omega ́ \sigma \kappa \omega$ in ThWNT 1:688-719 (TDNT 1:689-719) contains nothing that is helpful. 
Jacob, Moses, David, and with Jesus, is difficult to say, since it is not easy to speak of, classify and compare personal experience. The concepts of warning, humility, comfort, and security in the relation of Israelites, Jews, and followers of Jesus to the God whom they worship $^{78}$ are also present in Greek and Roman religion. However, the personal relationship based on covenant responsibilities that we find in the texts that define and describe Israel and the ekklesia of Jesus' followers is lacking in Greco-Roman texts. Greek and Roman religion was not about love for a deity, as Tom Carpenter points out: 'it was about a relationship between unequals where a mortal hopes for some sort of reciprocity for his or her offerings to the immensely more powerful god'. ${ }^{79}$ While Greeks and Romans can joyfully worship a deity, even speak of love, they seem to look for some material or social benefit. Although this utilitarian attitude characterised not a few Israelites, Jews, and Christians as well, it is not an exemplary, let alone central, aspect of the biblical understanding of God's relationship with his people whom he has chosen, whom he knows, and whom he loves as his children.

When interacting with Greeks and Romans who worshipped one or several of the traditional gods, the missionaries of the early churches would have wanted to emphasise that the one true God who created the world is all-powerful but not distant, omniscient but not domineering, actively involved in the affairs of the world but not arbitrary, personal but not vengeful. They pointed out that belonging to the one true God as doulos is predicated on the mercy of God who took the initiative to make them holy through the life, death, and resurrection of Jesus Messiah who is Lord, who calls rebellious sinners to be his holy people, and who loves them (1 Cor. 1:2). They emphasised that the one true God is a personal God who knows them and who loves them because he forgives them as they respond to the proclamation of the gospel (Rom. 1:7, in the context of Rom. 1:18-15:13). ${ }^{80}$

78 Cf. Rosner, 'Known by God', 219-25.

79 Tom H. Carpenter, 'Greek Religion and Art', in A Companion to Greek Religion, ed. D. Ogden (Chichester: Blackwell, 2010), 398-420, esp. 409.

80 An earlier version of the essay was presented as a paper at the May 28-29, 2015 conference at Ridley College, Melbourne, Australia exploring the theme 'Known by God'. 